\title{
EFFECTS OF SEX HORMONES ON GERMINAL CELLS OF THE RAT TESTIS : A RATIONALE FOR THE USE OF PROGESTIN AND ANDROGEN COMBINATIONS IN THE CONTROL OF MALE FERTILITY
}

\author{
C. TERNER AND JULIA MACLAUGHLIN \\ Biological Science Center, Boston University, \\ Boston, Massachusetts 02215, U.S.A.
}

\section{(Received 7th February 1972)}

\begin{abstract}
Summary. A biochemical test is described which reveals metabolic changes in isolated non-flagellate germinal cells of the rat testis within 4 days of treatment of the animals with sex hormones. By means of this test, a number of progestational compounds were surveyed and their minimum effective dose levels determined. Long-term treatment of male rats $(100$ to $400 \mathrm{~g})$ with a progestin $(0.5$ to $2.0 \mathrm{mg} /$ day $)$ caused atrophy of the secondary sex glands and decreased spermatogenesis with loss of libido. When atrophy of accessory sex glands was prevented by concurrent administration of testosterone (10 to $100 \mu \mathrm{g} /$ day), the animals continued to mate although the sperm count in the epididymis was severely depressed. All sex organs returned to normal after cessation of the treatment. These findings provide the background for the development of a male contraceptive combining a progestin with an androgen.
\end{abstract}

\section{INTRODUCTION}

The inhibitory action of the sex hormones on the production of pituitary gonadotrophins is well known. Of the three classes of sex steroids, the androgens, progestins and oestrogens, the latter are the most potent inhibitors. In a cytological study, Lacy \& Lofts (1965) showed that the treatment of male rats with oestrogen resulted in a decline of spermatogenesis which could be reversed by administration of FSH; they concluded that among the germinal cells, the spermatocytes are the most sensitive to the action of oestrogens. The administration of oestrogens to males has obvious disadvantages which preclude their use as contraceptive agents. Earlier attempts to induce sterility in males by administration of progestins were also found to produce unfavourable results. In a comprehensive survey of cytological changes during human spermatogenesis, Heller \& Clermont (1964) reported on the administration of norethandrolone, which resulted in azoospermia, but allowed the germ cells to develop to the stages of pachytene spermatocytes and step $a$ spermatids. Other progestins inhibited spermatogenesis in the rabbit and the ram (Ericsson, Dutt \& 
Archdeacon, 1964; Ericsson \& Dutt, 1965). Loss of libido was a serious drawback of treatment with progestins.

The present study was initiated by an attempt to measure the effect of antiandrogenic hormones on the metabolism of non-flagellate germ cells ('round cells') of the rat testis. These cells had been isolated from the seminiferous tubules after destruction of interstitial cells and found to be capable of synthesizing androgens from progesterone (Galena \& Terner, 1972). When it was observed that the rate of incorporation of $\left[{ }^{14} \mathrm{C}\right]$ glucose into the triglycerides of the round germinal cells was altered after treatment of rats with progestins for only a few days, a technique became available for rapidly testing a number of sex hormones and for determining their effective doses. It could then be shown that the atrophy of the testes and the accessory sex glands which occurred after prolonged treatment with progestins was prevented by concurrent treatment of the animals with small doses of testosterone propionate. On the other hand, the androgen did not reverse the suppression of spermatogenesis. Based on these findings, a rationale for the development of a male contraceptive is presented, combining a progestin in a dose adequate to suppress spermatogenesis with an androgen in an amount sufficient to maintain the normal functioning of the accessory sex glands and to preserve libido.

\section{MATERIALS AND METHODS}

\section{Animals}

Rats were purchased in sets of eight litter mates. Each set was divided into a control and an experimental group of four animals. When four comparable groups of animals were needed, these were made up by taking two rats from two sets of eight litter mates; in that way, each pair in any one group had two litter mates in each of the three other groups. In order to obtain litter mates, it was necessary to purchase young animals (100 to $150 \mathrm{~g}$ ). When fully grown rats were used, retired breeders ( 400 to $500 \mathrm{~g}$ ) were sorted out into sets of approximately equal weight and these were distributed into groups. The animals were allowed free access to Purina rat chow and water. The experimental animals were treated by daily subcutaneous injections of the drugs in peanut oil and the controls by injection of peanut oil alone. After killing by decapitation, the testes, epididymides, seminal vesicles and prostates from the rats in each group were combined and weighed.

\section{Incubation of germinal cells in vitro}

The combined testes of each group were homogenized in Krebs' phosphate saline (Krebs \& Eggleston, 1940) with a loosely fitting Potter homogenizer and incubated with $\left[{ }^{14} \mathrm{G}\right]$ glucose $(0.005 \mathrm{M}, 0.1 \mathrm{mCi} / \mathrm{mmol})$. After incubation for $90 \mathrm{~min}$ at $37^{\circ} \mathrm{C}$, the suspensions were chilled and the round cells were isolated by the following procedure, which was carried out in the cold. The tissue was sedimented at $600 \mathrm{~g}$, suspended in Krebs' saline and passed through a layer of Sephadex G-25 medium grade on a Buchner funnel. This retained the fragments of the tubules and the flagellated cells and allowed the round cells and red blood cells to fall through. The eluate was then centrifuged, the sedimented 
cells were suspended in a mixture of saline and water, 9:1 (v/v) to lyse the erythrocytes; the round cells which remained intact were resedimented and resuspended in isotonic saline. On inspection under the light microscope, the cell suspensions were seen to contain almost exclusively round cells (spermatocytes and early spermatids) and very few flagellated cells (late spermatids and spermatozoa). Although, in earlier studies, the round cells were isolated and then incubated with $\left[{ }^{14} \mathrm{C}\right]$ glucose, the procedure finally adopted was to incubate the crude testis homogenates first and isolate the round cells from the mixture after incubation. In this way, the time interval between the killing of the animals and the start of the incubation period was kept to a minimum, avoiding unintentional differential treatment of the round cells from the treated and the control groups of animals, which might have resulted from accidentally prolonged manipulation before incubation.

\section{Extraction of lipids}

The cells were homogenized in a mixture of chloroform: methanol, $2: 1(\mathrm{v} / \mathrm{v})$. The lipid extract was freed from water-soluble radioactive contaminants by passage through a Sephadex column (Terner, Szabo \& Smith, 1970). The purified lipids were then taken up in hexane and fractionated on a silicic acid column by a simplified elution procedure, in which the first fraction (mainly triglycerides) was eluted by $5 \%$ ether in hexane followed by $100 \%$ ether (which removed the remaining neutral lipids), $20 \%$ methanol in chloroform (cephalins) and 40\% methanol in chloroform (lecithin and some sphingomyelin). The lipid fractions were weighed and counted in Bray's solution (Bray, 1960) in a Packard Tri-Carb liquid scintillation counter. Specific activities of lipids were expressed as ct/min/mg lipid.

\section{Sperm counts in caput epididymidis}

To assess the changes in sperm production due to the various treatments, the number of spermatozoa in the caput epididymidis was determined. The organs of the animals of each group were combined, cut with scissors and homogenized in Krebs' saline. The gross débris was sedimented by centrifuging at slow speed, resuspended and resedimented. The supernatants were combined, made up to a known volume and the sperm count was determined in a haemocytometer.

\section{Mating tests}

Spayed female rats, after treatment with oestradiol ( $10 \mu \mathrm{g} /$ day) for 3 days and $0.5 \mathrm{mg}$ progesterone on the day of the test, were left with the males to be tested overnight. The females were then examined for the presence of vaginal plugs and spermatozoa. Males presumed to be azoospermic were tested by direct observation of mating.

\section{Reagents}

The $\left[{ }^{14} \mathrm{C}\right]$ glucose (randomly labelled) was purchased from the New England Nuclear Corporation. All progestational compounds were gifts from drug houses: cyproterone acetate from Berlin Laboratories, Inc.; ethynodiol diacetate and norethynodrel from G. D. Searle \& Co.; medroxyprogesterone acetate 
(Provera) and melengesterol acetate from the Upjohn Company; norgestrel from Wyeth Laboratories; chlormadinone acetate and norethindrone from Syntex Laboratories, Inc.; testosterone propionate was purchased from Calbiochem.

\section{RESULTS}

Incorporation of $\left[{ }^{14} \mathrm{C}\right]$ glucose into lipids of non-flagellate germ cells

When round cells, isolated from the germinal epithelium, were incubated with $\left[{ }^{14} \mathrm{C}\right]$ glucose, the lipids were found to be radioactive. Analysis of the lipids by chromatography on silicic acid columns showed the triglyceride fraction to have the highest specific activity. The round cells isolated from animals which had been treated with progestins in doses which caused atrophy of accessory sex glands differed from the cells of their litter mate controls in the rate of incorporation of glucose carbon into their triglycerides. The specific activities of the phosphatide fractions were lower and did not show consistent major changes due to treatment. The changes in specific activity of the triglycerides were therefore taken as an indication of the effectiveness of the hormone. An increase in the specific activity of the triglycerides of the round cells was observed after only 4 days of treatment, when the effects of the drugs on the accessory sex organs were still small and uncertain (Table 1).

Table 1. Effect of short-term treatment with progestin on lipid metabolism of germinal cells in male rats

\begin{tabular}{l|rc|cc}
\hline \multicolumn{1}{c|}{ Column fraction } & Control & Norethindrone & Control & $\begin{array}{c}\text { Ethynodiol } \\
\text { diacetate }\end{array}$ \\
\hline $\begin{array}{l}5 \% \text { ether/hexane } \\
\text { (triglycerides) }\end{array}$ & 4130 & 7400 & 2300 & 4640 \\
$\begin{array}{l}20 \% \text { methanol/chloroform } \\
\text { (cephalins) }\end{array}$ & 500 & 480 & 89 & 160 \\
$\begin{array}{l}40 \% \text { methanol/chloroform } \\
\text { (lecithin) }\end{array}$ & 444 & 476 & 160 & 160 \\
\hline
\end{tabular}

Eight male rats (litter mates) were allotted to two groups of four. The treated group received $1 \mathrm{mg}$ progestin/day, subcutaneously, for 4 days, the controls received peanut oil alone. At autopsy, the testes of each group were combined and the homogenates were incubated with $\left[{ }^{14} \mathrm{C}\right]$ glucose $(0.005 \mathrm{M}, 0.1 \mathrm{mCi} /$ mmol) for $90 \mathrm{~min}$. The non-flagellate cells of the germinal epithelium were isolated and their lipids extracted and fractionated on silicic acid columns. Specific activity of lipid fraction expressed in ct $/ \mathrm{min} / \mathrm{mg}$.

After administration of progestin for about 1 week or longer, a marked inhibition of labelling of triglycerides of the round cells (Table 2) accompanied the atrophy of the sex glands. When a short period of treatment was found to result in marked changes of lipid labelling, it became possible to carry out a rapid survey of a number of progestins and to determine their effective doses. In young rats $(100$ to $150 \mathrm{~g})$, the minimum dose level of progestins effective in altering the capacity of round cells to incorporate $\left[{ }^{14} \mathrm{C}\right]$ glucose into their triglycerides was 0.5 to $1.0 \mathrm{mg} /$ day. In fully grown animals $(400$ to $500 \mathrm{~g}$ ), the range was 0.5 to $2 \mathrm{mg} /$ day. 
Effect of progestins on male sex organs

After treatment for 1 to 4 weeks, the testes, epididymides and accessory sex organs decreased in weight, the prostates and seminal vesicles displaying the most clear-cut changes. In prolonged treatment of rapidly growing animals with a constant 1-mg dose, the effect of progestins on the ${ }^{14} \mathrm{C}$ labelling of round cell lipids seemed to have 'worn off' although the weights of the sex glands were

Table 2. Effect of progestins on ${ }^{14} \mathrm{C}$ labelling of lipids of germinal cells in male rats

\begin{tabular}{l|c|c|c}
\hline & $\begin{array}{c}\text { Length of } \\
\text { treatment } \\
\text { (days) }\end{array}$ & Triglycerides & Cephalins \\
\hline Control & 7 & 4750 & 463 \\
Melengesterol acetate & 7 & 2400 & 435 \\
Control & 9 & 4550 & 180 \\
Norgestrel & 9 & 2320 & 198 \\
\hline
\end{tabular}

Groups of eight littcr mates were treated as in Table 1. Progestins $(1 \mathrm{mg} /$ day) were given to $150-\mathrm{g}$ rats. Specific activity of lipid fractions of germinal cells expressed in ct $/ \mathrm{min} / \mathrm{mg}$.

still below the control weights (Table 3 ). Since the atrophy of the accessory glands indicated that the progestins in the doses used effectively suppressed steroidogenesis and the metabolic test suggested that they might also interfere with spermatogenesis, experiments were set up subjecting the animals to prolonged treatment with progestins to deplete them of their sperm reserves, while at the same time administering androgen in an attempt to maintain the accessory sex glands.

\section{Combination of progestin and androgen}

When injected together with a progestin, testosterone propionate in an unexpectedly low dose $(10 \mu \mathrm{g} /$ day $)$ prevented or diminished the inhibitory effects of a number of progestins when tested for periods of 2 to 6 weeks (Tables 3 to 5). The drugs tested were chlormadinone acetate, cyproterone acetate, ethynodiol diacetate, medroxyprogesterone acetate (Provera), melengesterol acetate, norethindrone, norethynodrel and norgestrel. Injection of the androgen alone caused an increase in the weights of the accessory glands but in prolonged treatment, it decreased the incorporation of $\left[{ }^{14} \mathrm{C}\right]$ glucose into triglycerides of the round cells (Tables 3 and 4). Provera and ethynodiol diacetate were selected for long-term testing in combination with testosterone propionate. After the animals had been treated with progestin and testosterone for at least 4 weeks, they were examined at autopsy. Testosterone effectively prevented the atrophy of the prostate gland and the seminal vesicles caused by Provera alone. It was less effective in counteracting ethynodiol diacetate which tended to keep the weights of the testes and the accessory glands low even in the presence of the androgen (Table 5). With this progestin, the accessory glands were maintained by $100 \mu \mathrm{g}$ testosterone/day. In the rats treated with progestin with or without 


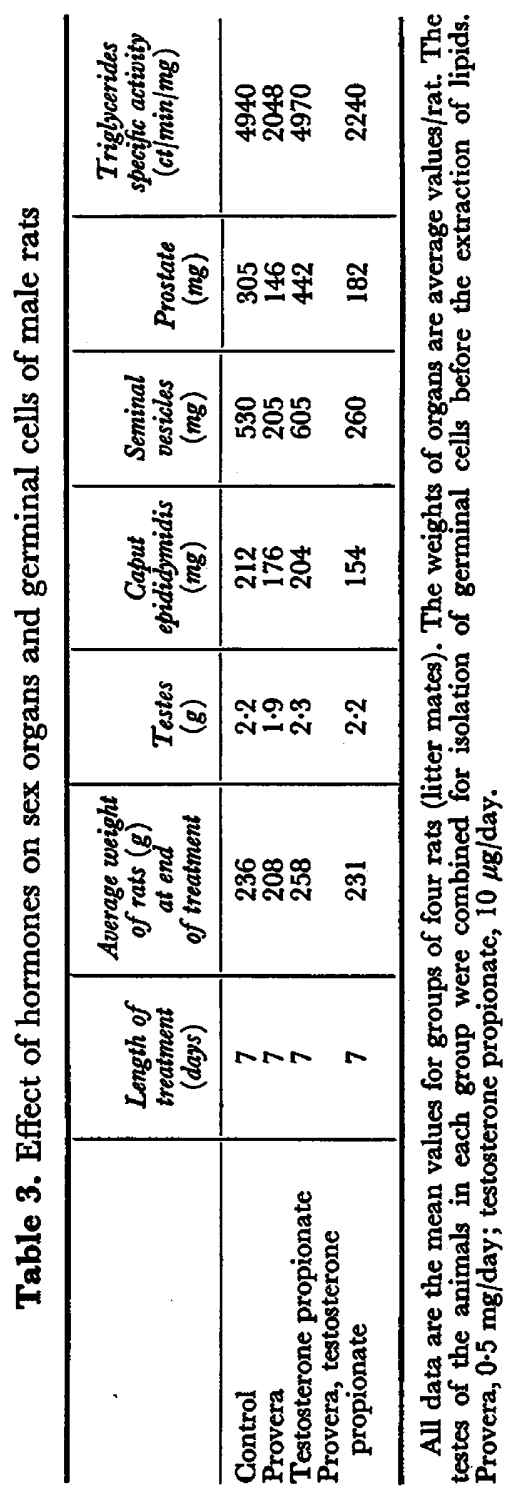




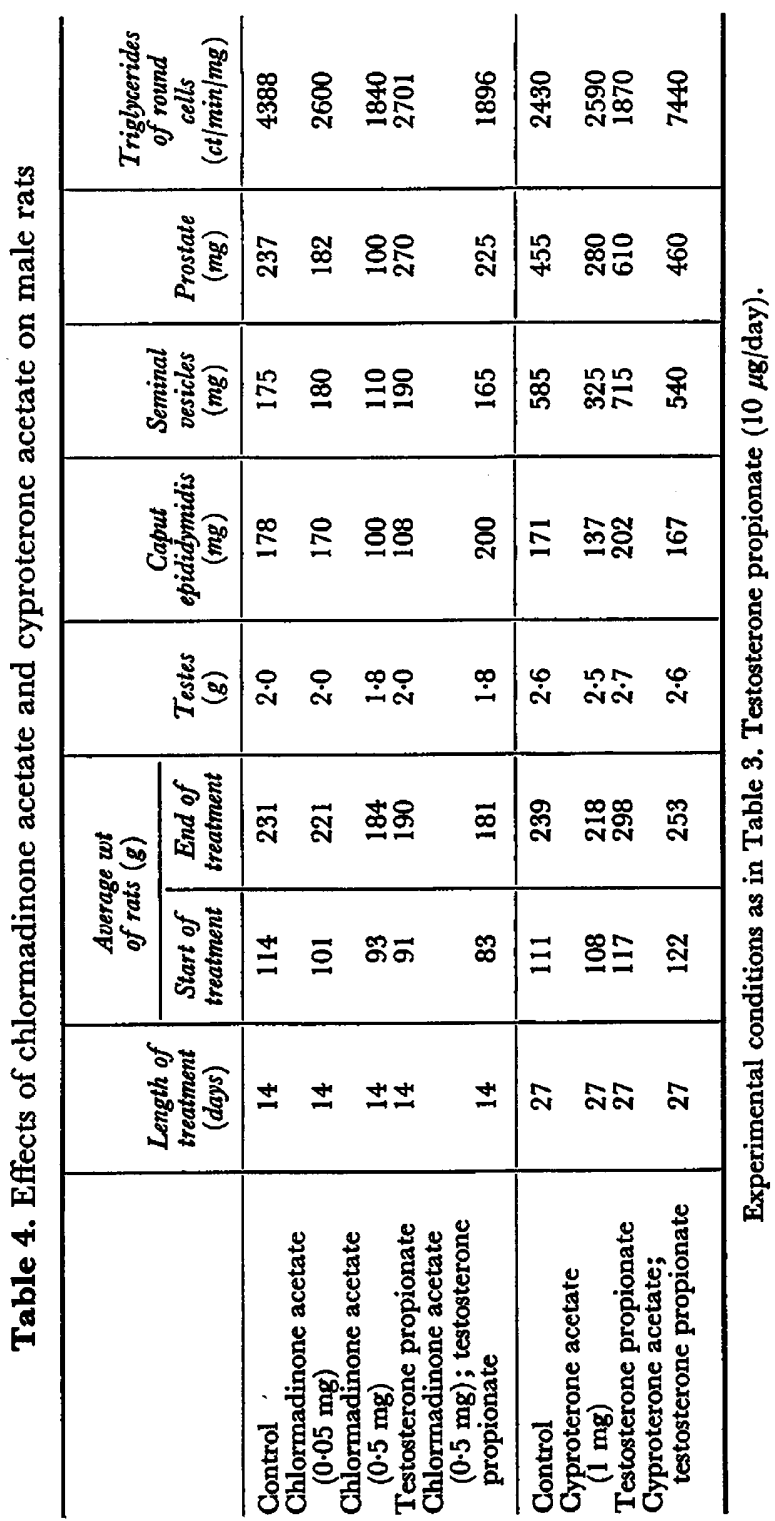




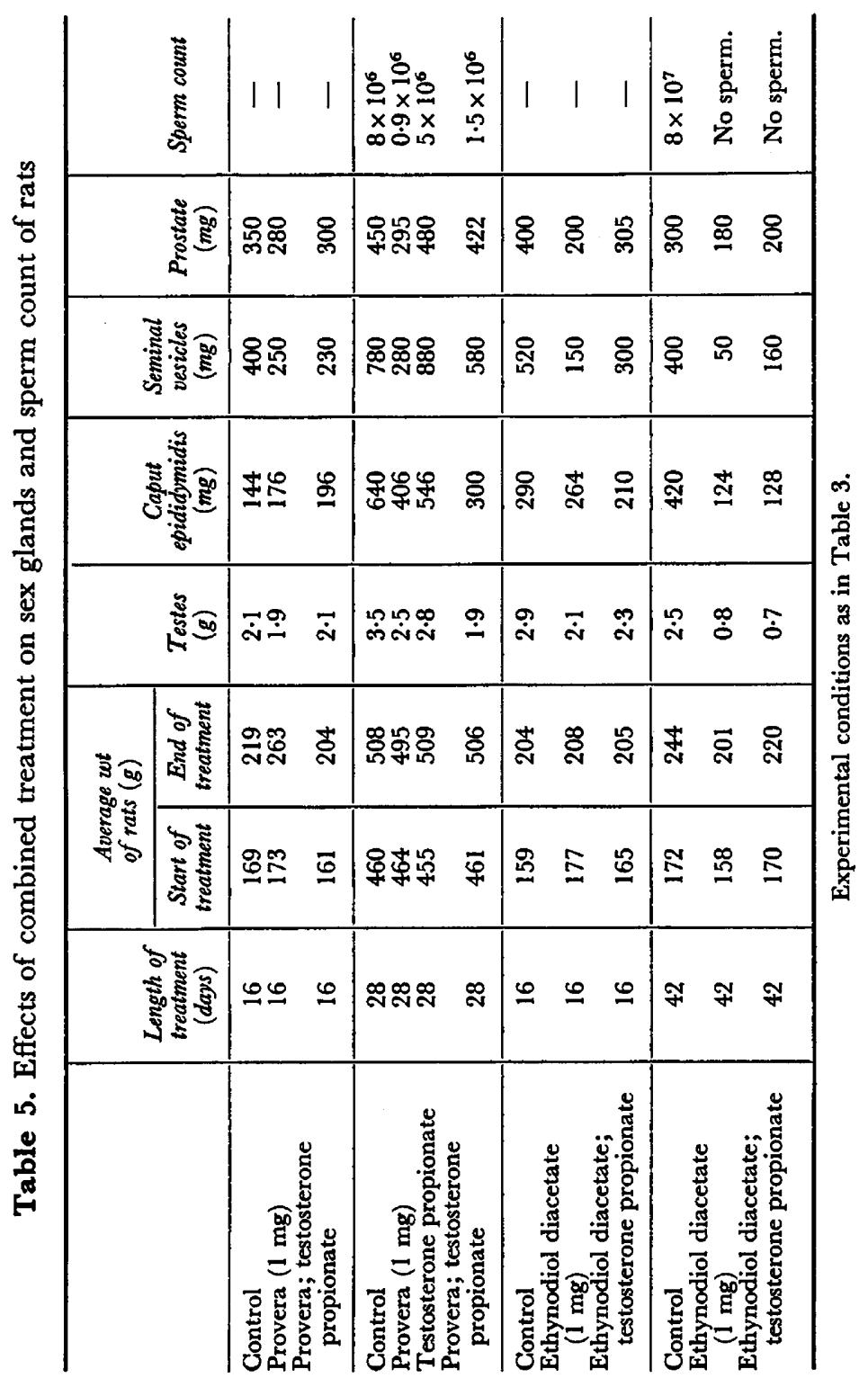


testosterone, the caput epididymidis was visibly smaller than that of the control and was virtually free from spermatozoa. The weight of the testes had also decreased.

\section{Recovery after cessation of treatment}

Fifteen animals were divided into three groups of five and treated with the hormones for 6 weeks. Three from each group were then killed and the organ weights and epididymal sperm counts were noted. The remaining animals were left without further treatment. When these were killed after a further period of 6 weeks, the testes and accessory sex glands of the animals which had been treated with progestin had recovered their weight and their epididymides were filled with spermatozoa.

\section{Mating behaviour}

When the mating behaviour was tested after 4 to 6 weeks of treatment, vaginal plugs and spermatozoa were found in female rats paired with male controls. No evidence of mating was found when the males had been treated with progestin alone. Animals treated with progestin plus androgen were observed directly and were seen to copulate.

\section{DISCUSSION}

\section{Antiandrogens}

If the use of progestins for the purpose of sterilizing the male has been discredited, it may be in part a consequence of the experimental approach taken in the past in which attention was focused on the inhibition by an antiandrogen of the stimulating effect of administered androgen. In one bioassay of antiandrogenic substances - the castrated mouse test - the weights of the prostates and seminal vesicles of castrated immature mice stimulated by administration of a standard dose of testosterone are taken as the base line; the decrease in weight of the accessory glands resulting from treatment with a progestin is taken as a measure of its activity (Dorfman, 1963). In another test in which intact rats were treated with large daily doses of androgens (e.g. $200 \mu \mathrm{g}$ testosterone), Kincl, Maqueo \& Dorfman (1965) observed inhibition of spermatogenesis, but excessive increases in the weights of the accessory sex glands; on the other hand, while administration of 19-norprogesterone and of chlormadinone $(0.2$ to $1.8 \mathrm{mg} /$ day) decreased ventral prostate and seminal vesicle weights, they had little effect on the weight of the testes.

\section{Combination of progestin and androgen in a male contraceptive}

Low doses of progestins were found to inhibit spermatogenesis in normal animals and the inclusion of a small amount of androgen prevented atrophy of the secondary sex glands. Our findings are compatible with the hypothesis that progestins in moderate doses act as antigonadotrophins restraining the production of FSH and ICSH sufficiently to inhibit both spermatogenesis and steroidogenesis. Replacement of the endogenous androgen by administration 
of small amounts of testosterone maintained the accessory sex glands without restoring spermatogenesis. At least in the doses employed in our study, there was no evidence for a competition of the progestins with testosterone for its receptor sites in the target organs, a mechanism suggested for cyproterone acetate by Steinbeck, Mehring \& Neumann (1971). In fact, quite low doses of testosterone $(10 \mu \mathrm{g})$ reversed the inhibitory effect of $1 \mathrm{mg}$ cyproterone acetate (Table 4). It is, however, possible that blocking of receptor sites may occur with the high doses $(10 \mathrm{mg})$ of cyproterone acetate employed by the Schering A.G. group.

\section{Side effects of progestins in the male}

In studies preceding our report, no attempt had been made to maintain the accessory sex glands, and with them libido and normal mating behaviour, by replacement of androgen. Consequently, loss of libido has been found to be one of the objectionable features of the use of progestins in males. In view of the present findings that the accessory sex glands remain functional while spermatogenesis is inhibited in rats treated with a combination of a progestin and an androgen, re-evaluation of all progestins is indicated, including those adversely commented upon. There should be relatively few obstacles to the administration of the new combinations to the human male, since the safety of most compounds has already been tested separately in both women and men.

Our experience, although still limited, suggests that the androgenic and oestrogenic side effects of progestins (see Edgren, 1969) may serve as a further aid in their selection. In the presence of Provera (androgenic), testosterone maintained both the prostate and the seminal vesicles but, in short-term treatment, the seminal vesicles remained suppressed. Ethynodiol diacetate (oestrogenic) seemed to cause a more drastic suppression of the testes and the accessory glands even when combined with higher doses of testosterone (Table 5).

The Schering A.G. group (Neumann, Steinbeck, Elger \& von BerswordtWallrabe, 1968; Steinbeck et al., 1971) has excluded cyproterone acetate from consideration as a possible male contraceptive because at least ten times as much of this progestin, even in high doses, is needed to inhibit spermatogenesis as will cause atrophy of the accessory sex glands.

As shown in Table 4, testosterone maintained the accessory sex glands in the presence of $0.5 \mathrm{mg}$ chlormadinone acetate/day. If re-evaluation of its safety should restore it to the list of safe drugs, further testing would be indicated.

It is therefore suggested that for the purpose of suppression of male fertility, a progestin with an androgenic side effect may be the compound of choice since this may facilitate the maintenance of the accessory sex glands.

\section{Effect of testosterone on spermatogenesis}

The view that ICSH acts exclusively on the Leydig cells and FSH on the germinal epithelium has long been considered untenable. The two gonadotrophins are believed to act synergistically, ICSH supplementing the action of FSH on the seminiferous tubules. It has been suggested that the response of the germinal epithelium to ICSH is indirect, evoked by the androgen produced by the directly stimulated Leydig cells. On the other hand, this side effect has 
been attributed to an impurity which may be present in preparations of ICSH (see Hooker, 1970).

It has long been known that androgens maintain spermatogenesis in hypophysectomized rats; that, in experiments in which atrophy of the sex glands had been produced by oestrogen, testosterone supports the seminiferous tubules; and that, in intact rats, it can increase sperm production (see Pincus, 1965). Inspection of the data quoted by Pincus reveals that those effects were produced by high doses of androgen ( $500 \mu \mathrm{g} /$ day/rat.) In other experiments quoted, the administration to intact rats of $200 \mu \mathrm{g}$ testosterone/day inhibited spermatogenesis but caused excessive increases in the weight of the accessory sex glands.

In the progestin-treated animals of the present study, only a slight stimulating effect on spermatogenesis could be observed on administration of $100 \mu \mathrm{g}$ testosterone. This was insignificant compared with the marked response of the accessory sex glands. The results of the present study show that, in the absence of ICSH, testosterone, at least in the dose used, is unable to maintain spermatogenesis at a functional rate. It therefore seems possible to adjust minimum doses of progestins and androgens in combinations which repress spermatogenesis to the point of infertility while keeping the accessory sex glands functional and ensuring normal sex drive and activity. Experimental determination of dosages effective in the human male when administered by an acceptable route may open up the application of the principle outlined in this paper to control male fertility.

\section{AGKNOWLEDGMENTS}

This investigation was supported by a research contract from NICHD, National Institutes of Health. The assistance of Rico Autori and Henry Talberth (dental students, NIDR summer research participants) and Howard Cohen (NSF undergraduate research participant) is acknowledged.

\section{REFERENCES}

BrAY, G. A. (1960) A simple, efficient liquid scintillator for counting aqueous solutions in a liquid scintillation counter. Analyt. Biochem. 1, 279.

Dorfman, R. I. (1963) Anti-androgens in a castrated mouse test. Steroids, 2, 185.

EDGReN, R. A. (1969) The biology of steroidal contraceptives. In: Contraception: The Chemical Control of Fertility, p. 23. Ed. D. Lednicer. Marcel Dekker, New York.

ERICsson, R. J. \& Dutr, R. H. (1965) Progesterone and $6 \alpha$-methyl-1 $7 \alpha$-hydroxyprogesterone acetate as inhibitors of spermatogenesis and accessory gland function in the ram. Endocrinology, 77, 203.

Ericsson, R. J., Dutt, R. H. \& Archdeacon, J. W. (1964) Progesterone and 6-chloro-6,17-acetoxyprogesterone as inhibitors of spermatogenesis in the rabbit. Nature, Lond. 204, 261.

Galena, H. J. \& Terner, C. (1972) Biosynthesis of androgens by isolated spermatocytes and spermatids of rat testis. (Abstract). Fedn Proc. Fedn Am. Socs exp. Biol. 31, 295.

Heller, C. G. \& Clermont, Y. (1964) Kinetics of the germinal epithelium in man. Recent Prog. Horm. Res. 20, 545.

Hooker, G. W. (1970) The intertubular tissue of the testis. In: The Testis, Vol. 1, p. 514. Eds. A. D. Johnson, W. R. Gomes and N. L. VanDemark. Academic Press, New York.

Kincl, F. A., MaQueo, M. \& Dorfman, R. I. (1965) Influence of various steroids on testes and accessory sex organs in the rat. Acta endocr., Copenh. 49, 145.

KREBs, H. A. \& EgGleston, L. V. (1940) Oxidation of pyruvate in pigeon breast muscle. Biochem. $\mathcal{F}$. $34,442$. 
LACY, D. \& Lofts, B. (1965) Studies on the structure and function of the mammalian testis. I. Cytological and histochemical observations after continuous treatment with oestrogenic hormone and the effects of F.S.H. and L.H. Proc. R. Soc. B, 162, 188.

Neumann, F., Steinbeck, H., Elger, W. \& von Berswordt-Wallrabe, R. (1968) Hoden-Morphologie und -Funktion unter der Einwirkung von PMS und HCG bei gleichzeitiger AntiandrogenBehandlung. Acta endocr., Copenh. 57, 639.

Pincus, G. (1965) The control of fortility, pp. 14, 30-35. Academic Press, New York.

Steingeck, H., Mehring, M. \& Neumann, F. (1971) Comparison of the effects of cyproterone, cyproterone acetate and oestradiol on testicular function, accessory sexual glands and fertility in a long-term study on rats. J. Reprod. Fert. 26, 65.

Terner, C., Szabo, E. I. \& Smith, N. L. (1970) Separation of gangliosides, corticosteroids and watersoluble non-lipids from lipid extracts by Sephadex columns. 7. Chromat. 47, 15. 